\title{
Immunohistochemical evaluation of Her-2/neu overexpression in breast carcinoma in Mosul
}

\author{
Shuaib H. Saleem*; Mohammed S. Saeed ${ }^{* *}$; Nadwa S. Mustafa ${ }^{* * *}$ \\ Department of Pathology; College of medicine; University of Mosul
}

(Ann. Coll. Med. Mosul 2008; 34(2): 87-92).

Received: $20^{\text {th }}$ May 2008; Accepted: $24^{\text {th }}$ Sept 2008.

\begin{abstract}
Objective: To evaluate the overexpression of Her-2/neu in patients with breast cancer in Mosul (both invasive and intraductal) against other prognostic parameters of mammary carcinomas, such as histological type, grade, tumor size, patient age and number of lymph nodes involved.

Methods: This is a retrospective study conducted in the Pathology laboratory of Al-Jamhoori Teaching Hospital and at private laboratories. A total of 36 breast cancer cases and 4 benign cases were diagnosed and collected in a period spanning from April 2006 to April 2007. We used Immunohistochemistry to evaluate the overexpression of Her-2/neu against the age, tumor size, type and grade and the axillary lymph node status.

Results: The mean age of all cases was 47.5 years ranging from 28 to 72 years. Regarding the age, Her-2 positivity was shown in 2 peaks ( $4^{\text {th }}$ and $7^{\text {th }}$ decades), while Her-2 negativity was found in older age group $(p=0.004)$. Overall Her-2 overexpression was in $37 \%$ of the cases; it was overexpressed in $34.5 \%$ of invasive ductal carcinoma, in $100 \%$ of medullary carcinoma and in $100 \%$ of ductal carcinoma in situ. Whereas no expression (0.0\%) was seen in 3 cases of invasive lobular carcinoma and one case of colloid carcinoma. Her-2 positivity was associated with large size (T2 and T3) rather than small size tumors $(p=0.015)$. There was a correlation between Her-2 positivity and high grade tumor [ $G 3$ in $69.2 \%$ of the positive cases $(p=0.045)]$. Her- 2 positivity was associated with axillary lymph node metastasis in $84.6 \%$ of cases, but not reaching a statistical significance. The benign lesions included in this study (two fibroadenoma, one fibrocystic disease and one duct ectasia) all showed negativity for Her-2 stain.

Conclusion: Her-2 overexpression was found in $37 \%$ of breast cancer in Mosul. Regarding age incidence Her-2 overexpression was noted at 2 peaks $3^{\text {rd }}$ and $6^{\text {th }}$ decades. Large size and high grade breast carcinomas were associated with high percentage of Her-2 positivity, and the majority of Her-2 positive cases had axillary lymph node metastases.
\end{abstract}

Key words: Breast carcinoma, Her-2/neu expression

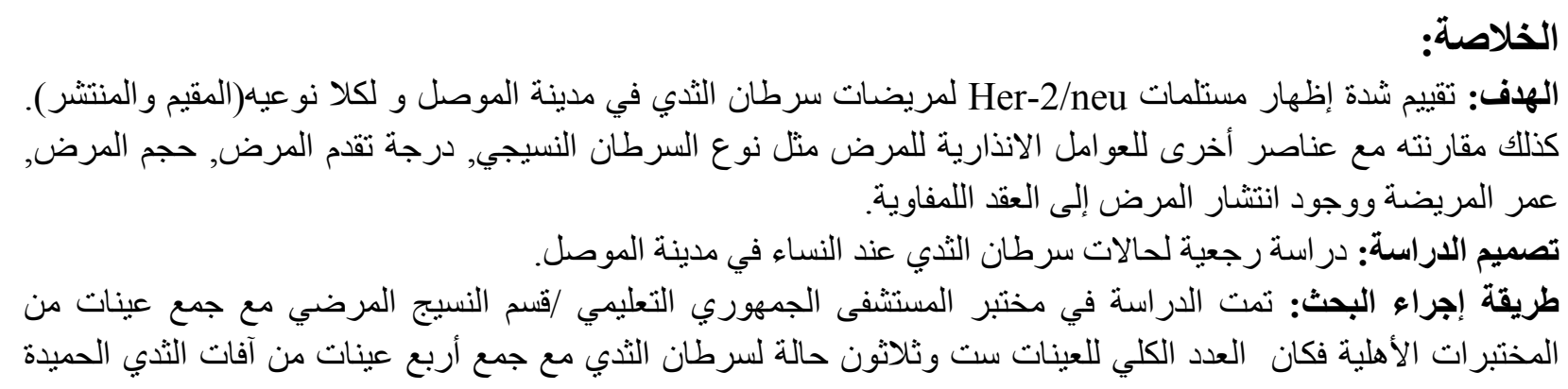




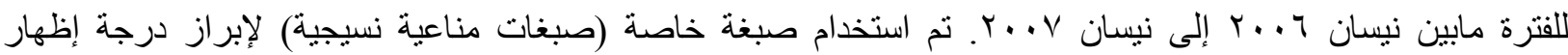

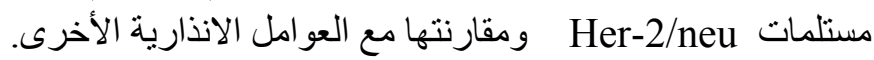

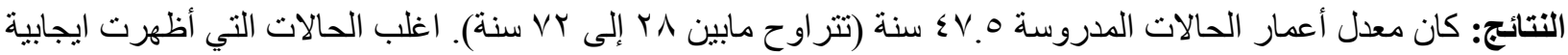

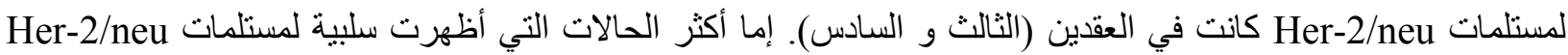
ففي الفئات العمرية الأكبر. كانت نسبة ايجابية إظهار مستلمات Her-2/neu هو الإيجابية هي من نوع سرطان الثذي القنوي الانتشاري, كما كانت شدة الظهار للمستلمات أكثر مع الإحجام الأكبر للسرطان

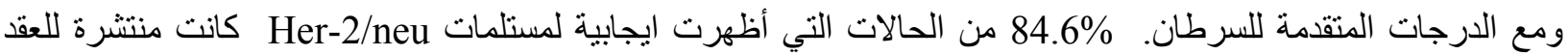
اللمفاوية.

الاستنتاج: نسبة ايجابية إظهار مستلمات لسرطان الثذي في مدينة الموصل كانت 37\%. وخاصة في العقدين الثالث و السادس الاس الثان وفي الأورام الأكبر حجما وفي الدرجات المتقدمة للسرطانات. معظم الحالات الإيجابية كانت منتشرة للعقد اللمفاوية.

G rowth and differentiation of both normal and malignant human breast cancer cells are regulated by steroid hormone and peptide growth factor receptors. Among the peptide growth factor receptors frequently implicated in breast cancer are members of type I receptor tyrosine kinase family which is encoded by Her-2/ neu gene ${ }^{(1)}$. The Her$2 /$ neu (c-erb B-2) gene is protooncogen localized to chromosome $17 q$ that encodes a $185 \mathrm{kd}$ transmembrane glycoprotein with tyrosine kinase activity and structural homology to the human epidermal growth factor receptor ${ }^{(2,3)}$. Tyrosine kinase receptor family is involved in cell-cell and cell-stromal interaction, primarily through a process known as signal transduction, in which external growth factors, or ligands, affect the transcription of various genes by phosphorylating or dephosphorylating a series of transmembrane proteins and intracellular signaling intermediates ${ }^{(4)}$.

Oncogenic amplification of Her-2/neu gene has been observed in 20\%-30\% of all invasive breast cancer and most cases of intraductal comedocarcinoma $^{(2,5)}$. However; some studies had found that about $20 \%-40 \%$ of breast cancer showed amplification of Her$2 /$ neu $^{(6)}$. Her-2/neu amplification in breast cancer cases predicts more frequent relapse, short survival time and is considered as independent poor prognostic factor ${ }^{(2,7)}$. Cancer cells that overexpress Her-2/neu are often resistant to many cytotoxic drugs and radiotherapy. A humanized monoclonal antibody, Trastuzumab (Herceptin) can effectively treat tumor with Her-2 gene amplification in $25 \%$ of patient as monotherapy and $50 \%$ when given with other chemotherapy ${ }^{(4)}$.

Because the clinical results obtained with Herceptin are promising, there is a need for a sensitive, precise and reproducible methods to screen breast cancer patients for amplification of Her-2/neu gene. The most common detection methods for Her-2/neu include; measurement of protein overexpression by immunohistochemical assay (Herceptest), detection of gene amplification by fluorescence in situ hybridization (FISH) technique and PCR technique ${ }^{(2,8)}$.

Our aims in this study are: (1) to evaluate the overexpression of Her-2/neu in patients with breast cancer in Mosul (both invasive and intraductal) and (2) to compare the expression of this with other prognostic parameters of mammary carcinomas, such as histological type, tumor grade, tumor size, patient's age and number of lymph nodes metastases.

\section{Materials and methods:}

A total of 36 breast cancer cases and 4 benign cases were diagnosed in a period from April 2006 to April 2007. Cases were collected from Al-Jamhoori surgical teaching hospital and from private laboratories. The cases were classified according to WHO classification. Age and sex of patients and the size of each 
tumor were considered. Nottingham combined histologic system was used for grading.

All cases underwent axillary clearance and the state of regional lymph nodes, the presence or absence of periductal fibrosis, necrosis and the lymphatic or vascular invasion were assessed.

Sections were cut at $4 \mu \mathrm{m}$ thickness from paraffin blocks, mounted onto silanized slides and let to dry at $60^{\circ} \mathrm{C}$ in the oven for 60 minutes. Sections then deparaffinized and rehydrated by descending grades (95\%$100 \%$ ) of ethanol and distilled water. Antigen retrieval was achieved by heat-treat at $95^{\circ} \mathrm{C}$ in water bath for 40 minutes, then left to cool at room temperature. Slides were quenched with 3\% methanolic hydrogen peroxide for 5 minutes, followed by washing with Trisbuffered saline (TBS). Slides were incubated with $100 \mu$ l of primary antibody for 30 minutes at room temperature in a moisture chamber, then rinsed with TBS. After which followed by application of secondary antibody for 30 minutes and then washed by TBS to remove excess of TBS and followed by adding 3,3 diaminobenzidine tetrahydrochloride as a chromogen for 10 minutes to produce the characteristic brown stain. A counter stain of hemotoxylin for 15 seconds was used to give better view. The final stages were drying and mounting coverslides.

For each run of staining, positive and negative control slides were also prepared. A positive control was taken from provided control slides from Dako for different scores of Her-2/neu. The negative controls were prepared from a known case of Her-2/neu positive block with substitution of primary antibody by negative control reagent.

Her-2/neu was scored on a 0 to 3 scale according to the criteria set by Dako. The staining was scored as negative (0) when no membrane staining was observed, or when membrane staining was observed in less than $10 \%$ of tumor cells. Weak positive (1+) if weak focal membrane staining was seen in more than $10 \%$ of tumor cells. Intermediate $(2+)$ if weak to moderate, complete membrane staining was seen in more than $10 \%$ of tumor cells. Strongly positive (3+) if intense complete membrane staining with weak to moderate cytoplasmic activity was seen in more than $10 \%$ of tumor cells. In final analysis score 0 and $1+$ were considered negative, score 2+ was considered weakly positive and score $3+$ was considered as strongly positive.

\section{Results:}

Thirty six mastectomy specimens were included in this study. Invasive ductal carcinoma formed the majority of the cases (29 cases). The second type was invasive lobular carcinoma (3 cases). There were 2 cases of ductal carcinoma in situ, one case of medullary carcinoma and one case of colloid carcinoma (Table 1).

Four $(17.4 \%)$ were in $\mathrm{G} 1,6$ cases out of 36 (20.1\%) were in $\mathrm{G} 2$ and 13 cases were in $\mathrm{G} 3$ (56.5\%), (Table 2).

Two thirds of cases (24) had size ranged between $(2-5 \mathrm{~cm})$ T2, 9 cases (25\%) were T3, while the remaining 3 cases (8.3\%) were small size $\mathrm{T} 1$ less than $2 \mathrm{~cm}$. (Table 3 ).

The mean age of all cases was 47.5 years ranging from 28 to 72 years. Her-2 positivity was shown in 2 peaks in two age groups ( $4^{\text {th }}$ and $7^{\text {th }}$ decades). While Her-2 negative cases were seen in older age group. The difference is statistically significant $(\mathrm{p}=0.004)$ (Table 4).

Her-2 was overexpressed in $13(37 \%)$ tumors, nine of them showed strong positivity score $(+3)$ and 4 scored (+2). There were 23 cases with negative reaction to Her-2. There was a strong correlation between Her-2 overexpression and tumor size (T2 and T3) (6 cases of each size) $(p=0.015)$. While most negative cases were in T2 (24 cases). Also we found a positive correlation between Her-2 positivity and high grade of tumor $69.2 \%$ ( 9 cases were $G 3)(p=0.045)$.

The study of the lymph node status showed 31 tumors with positive metastasis, and 5 cases with negative lymph node metastasis. Her-2 overexpression was associated with lymph node metastasis in 11 (84.6\%) cases, and with no lymph node metastasis in 2 $(15.4 \%)$ cases. There was no statistical correlation between lymph node metastasis and Her-2 positivity (Table 5).

All of the four benign lesions included in this study were negative for Her-2 stain. 
Table 1: The histological types of breast carcinoma versus Her-2 results

\begin{tabular}{|c|c|c|c|c|c||}
\hline \multirow{2}{*}{ Types of Tumor } & \multicolumn{2}{|c|}{ Her-2 (+ve) } & \multicolumn{2}{|c|}{ Her-2 (-ve) } & \multirow{2}{*}{ Total } \\
\cline { 2 - 5 } & No. & $\%$ & No. & $\%$ & \\
\hline Invasive ductal carcinoma & 10 & 34.5 & 19 & $\mathbf{6 5 . 5}$ & 29 \\
\hline Medullary carcinoma & 1 & 100 & $\mathbf{0}$ & $\mathbf{0 . 0}$ & 1 \\
\hline Colloid carcinoma & $\mathbf{0}$ & $\mathbf{0 . 0}$ & $\mathbf{1}$ & $\mathbf{1 0 0}$ & $\mathbf{1}$ \\
\hline Ductal carcinoma in situ & $\mathbf{2}$ & $\mathbf{1 0 0}$ & $\mathbf{0}$ & $\mathbf{0 . 0}$ & $\mathbf{2}$ \\
\hline Invasive lobular carcinoma & $\mathbf{0}$ & $\mathbf{0 . 0}$ & $\mathbf{3}$ & $\mathbf{1 0 0}$ & $\mathbf{3}$ \\
\hline Total & 13 & - & $\mathbf{2 3}$ & $\mathbf{2 3}$ & $\mathbf{3 6}$ \\
\hline
\end{tabular}

Table 2: Tumor grade against Her-2 results

\begin{tabular}{|c|c|c|c|c||}
\hline Tumor grade & \multicolumn{2}{|c|}{ Her-2 (+ve) } & \multicolumn{2}{c||}{ Her-2 (-ve) } \\
\hline G1 & No. & $\%$ & No. & $\%$ \\
\hline G2 & 0 & 0.0 & 4 & 17.4 \\
\hline G3 & 4 & 30.8 & 6 & 20.1 \\
\hline Total & 9 & 69.2 & 13 & 56.5 \\
\hline
\end{tabular}

Table 3: Tumor size against Her-2 results.

\begin{tabular}{||c|c|c|c|c|c|c||}
\hline \multirow{2}{*}{ Tumor size (cm) } & \multicolumn{2}{|c|}{ Her-2 (+ve) } & \multicolumn{2}{c|}{ Her-2 (-ve) } & \multicolumn{2}{c|}{ Total } \\
\cline { 2 - 7 } & No. & $\%$ & No. & $\%$ & No. & $\%$ \\
\hline \hline T1 $(<2 \mathrm{~cm})$ & 1 & 7.6 & 2 & 8.7 & 3 & 8.3 \\
\hline T2 (2-5 cm) & 6 & 46.2 & 18 & 78.3 & 24 & 66.7 \\
\hline T3 $>5 \mathrm{~cm})$ & 6 & 46.2 & 3 & 13.0 & 9 & 25.0 \\
\hline Total & 13 & 100 & 23 & 100 & 36 & 100 \\
\hline
\end{tabular}

Table 4 : Age group versus Her-2 results.

\begin{tabular}{||c|c|c|c|c|c|c||}
\hline \multirow{2}{*}{ Age (year) } & \multicolumn{2}{|c|}{ Her-2 (+ve) } & \multicolumn{2}{c|}{ Her-2 (-ve) } & \multicolumn{2}{c||}{ Total } \\
\hline & No. & $\%$ & No. & $\%$ & No. & $\%$ \\
\hline \hline $20-30$ & 1 & 7.7 & 1 & 4.4 & 2 & 5.6 \\
\hline $31-40$ & 4 & 30.8 & 2 & 8.7 & 6 & 16.7 \\
\hline $41-50$ & 2 & 15.4 & 8 & 34.8 & 10 & $\mathbf{2 7 . 8}$ \\
\hline $51-60$ & 2 & 15.4 & 4 & 17.4 & 6 & 33.3 \\
\hline$>60$ & 4 & 30.8 & 8 & 34.8 & 12 & 100 \\
\hline Total & 13 & 100 & 23 & 100 & 36 & \\
\hline
\end{tabular}

Table 5: Lymph node status versus Her-2 results.

\begin{tabular}{|c|c|c|c|c|c|c||}
\hline \multirow{2}{*}{} & \multicolumn{2}{|c|}{ Her-2 (+ve) } & \multicolumn{2}{c|}{ Her-2 (-ve) } & \multicolumn{2}{c|}{ Total } \\
\cline { 2 - 7 } & No. & $\%$ & No. & $\%$ & No. & $\%$ \\
\hline L.N Positive & 11 & 84.6 & 20 & 87.0 & 31 & 86.1 \\
\hline L.N Negative & 2 & 15.4 & 3 & 13.0 & 5 & 13.9 \\
\hline Total & 13 & 100 & 23 & 100 & 36 & 100 \\
\hline
\end{tabular}




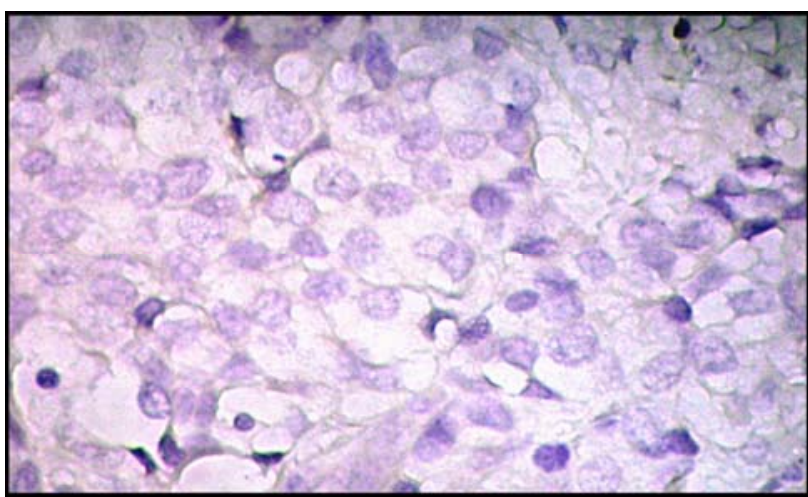

Figure 1: Score 0 (Her-2 negativity) (No staining is observed, or faint membrane staining present in less than $10 \%$ of the tumor cells) (40x)

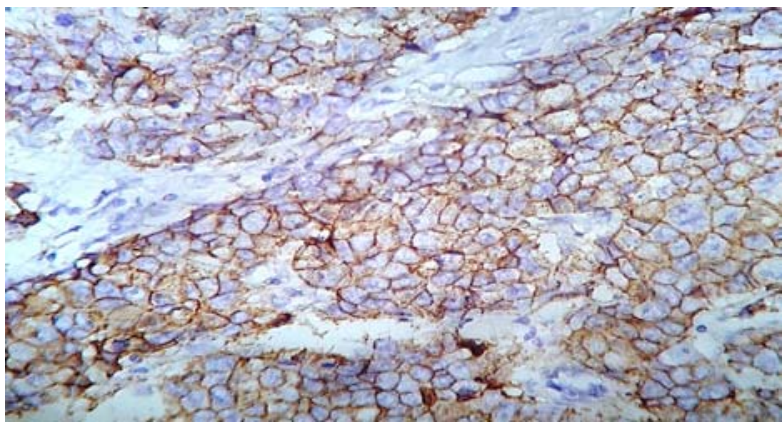

Figure 3: Score 2+ Her-2 positivity (weak to moderate complete membrane staining in more than $10 \%$ of the tumor cells) (40x)

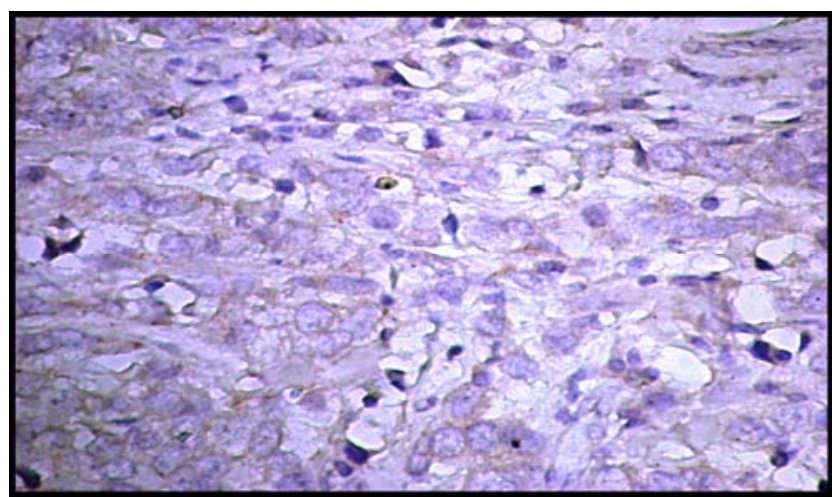

Figure 2: Score 1+ (Her-2 negativity) (A faint/barely perceptible incomplete membrane staining detected in more than $10 \%$ of the tumor cells) (40x)

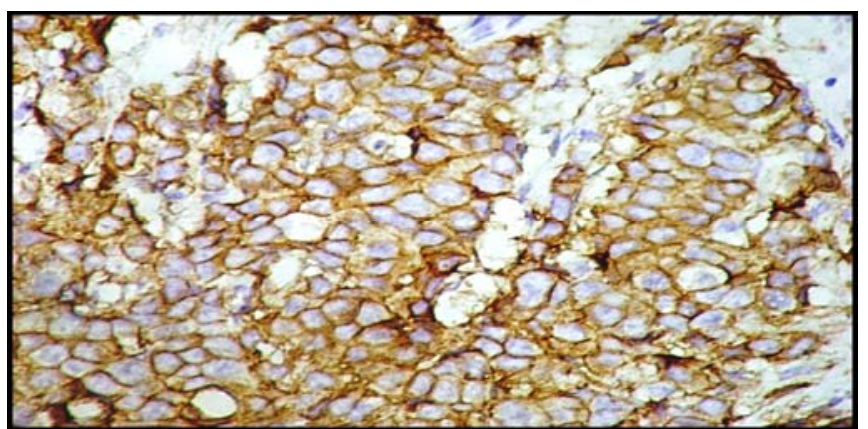

Figure 4: Score 3+ Her-2 positivity (Strong complete membrane staining in more than $10 \%$ of the tumor cells) (40x)

the $4^{\text {th }}$ decade and the other in the $7^{\text {th }}$ decade. Most of the Her-2 negative cases were found in patient over the age of 60 years. Statistical correlation between Her-2 overexpression and age is significant. Two studies from different countries, one showed peak of Her-2 positivity in younger females ${ }^{(10,12)}$, and another with a peak of Her-2 positivity in older females ${ }^{(6)}$.

Her-2 was overexpressed in 10 (34.5\%) out of 29 cases of invasive ductal carcinoma and in one case $(100 \%)$ of medullary carcinoma and in 2 cases $(100 \%)$ of ductal carcinoma in situ. This is in comparison to none case of invasive lobular carcinoma and none case of colloid carcinoma (0.0\%). Our results are comparable with the data in the literature ${ }^{(3,10)}$.

There was a strong correlation between Her2 overexpression and tumors of large size and of high grade, as most of the cases with Her-2

overexpression, there were 2 peaks, one in 
positivity were appointed with $\mathrm{G} 3$, this is consistent with others ${ }^{(10,12-14)}$.

Although 11 cases out of 13 with Her-2 overexpression showed lymph node metastasis, statistically, there was no significant correlation. This may be due to the low number of studied cases as compared to a study from Jordan $^{(10)}$. On the other hand a different study found a strong correlation between Her-2 overexpression and lymph node metastasis ${ }^{(15)}$.

\section{Conclusion:}

Her-2 overexpression was found in $37 \%$ of breast cancer in Mosul. There were 2 peaks of age incidence in relation to Her-2 positivity at $4^{\text {th }}$ and $7^{\text {th }}$ decades. It predicts poor prognosis which is compatible with other poor prognostic factors. Large size and high grade breast carcinomas were associated with high percentage of Her-2 positivity, and the majority of Her-2 positive cases had axillary lymph node metastasis.

\section{References:}

1. Gottfried Konecy, Giovanni Pauletti, Mark Pegram, Michael Untch, et al. Quantitative Association between her-2/neu and steroid hormone receptor-positive primary breast cancer. Journal of National Cancer Institute 2003;95(2):15

2. Melanie Konigshoff, Joehen Wilhelm, Rainer M. Bohle, Alfred pingoud, et al. HER-2/neu gene copy number quantified by real time PCR: comparison of gene amplification, hetrozygosity and immunohistochemical status in breast cancer tissue. Clinical Chemistry 2003;49:219-299

3. Russel Vang, Linda D. Cooleg, Wilbur R. Harrison, Tommy Reese, et al. immunohistochemical determination of HER$2 /$ neu expression in invasive breast cancer. Am J Clin Pathol 2000; 113:669-674

4. Jeffery S. Ross, Jonathan A Fletcher, Kenneth J. Targeted Therapy in breast cancer, the HER-2/neu gene and protein. Molecular and Cellular proteomics 2004;3:379-398

5. Pinto A.E., S. Andre, Percira T., Nobrega S., et al. C-erb-2 oncoprotein overexpression identifies subgroup of estrogen receptors positive $(E R+)$ breast cancer patient with poor prognosis. Annals of Oncology 2001;12:525-533

6. Kakil I. Rasul, Kelta Mohammed, Awidi S. Abdulla, et al Study of HER-2/neu status in Qatari women with breast carcinoma. Saudi Medical Journal 2000;24(8):832-836

7. Ashraf Hoque, Nour Sneige, Ausegul A., et al. HER-2/neu gene amplification in ductal carcinoma in situ of the breast cancer epidemiology Biomarkers and Prevention 2003;11(6):587-590

8. Michael J. Duffy. Predictive Markers in breast and other cancer: a review. Clinical Chemistry 2005;51(2):494-503

9. Reis JS, Filho and Tutt A N J. Triple negative tumors: A clinical review. Histopathology 2008; 52:108-118

10.Almasari N.M. and Alhamed Mohammad. Immunohistochemical evaluation of human epidermal growth factor receptor-2, estrogen and progesterone receptors in breast carcinoma in Jordan. Breast Cancer Research 2005;24 (5)

11.Revillion F, Bonneterre J, Peyrat JP. Erb-B2 oncogene in human breast and its clinical significance. European $\mathrm{J}$ Cancer 1998;34(6):791-808

12.El-A Helal T, Khalifa A, Kamel AS. Immunohistochemical expression of p53 and c-erb-b2 in breast cancer in Egypt. Anticancer Research 2000,20(3B):2145-50

13. Hoff ER, Tubbss RR, Myles JL, et al. Her$2 /$ neu amplification in breast cancer :stratification by tumor type and grade. Am J Pathol 2002;117(6): 916-21

14.Sathiyamoorthy Selvarajen, Ka Yan Wong, Keisiong Khoo, et al. Overexpression of $\mathrm{C}^{-}$ erb-B2 correlates with nuclear morphometry and prognosis in breast carcinoma in Asian women. Pathology 2006;38,6(12):528-533

15. Hartman LC, Ingle JN, Wold LE, et al. Prognostic value of c-erb-B2 overexpression in axillary lymph node positive breast cancer result from randomized adjuvant treatment protocol. Cancer 1994;74(11): 2956-63. 